\title{
Antioxidant and Chemosensitizing Effects of Flavonoids with Hydroxy and/or Methoxy Groups and Structure-Activity Relationship
}

\author{
J u-Mi J eong ${ }^{1,3}$,Su-Kyeong Kang ${ }^{2}$, In-Hwa Lee ${ }^{3}$, J i-Yoon Lee ${ }^{1}$, Hyuk J ung ${ }^{4}$ and Cheol-Hee Choi ${ }^{1}$ \\ ${ }^{1}$ Research Center for Resistant Cells and Department of Pharmacology, Chosun University Medical School, Gwangju, \\ South Korea; ${ }^{2}$ Department of Beauty Science, Gwangju Women's University,Gwangju, South Korea; ${ }^{3}$ Department of \\ Environmental Engineering and BK21 Team for Bio Hydrogen Production, Chosun University, Gwangju, South Korea; \\ ${ }^{4}$ Department of Obstetrics and Gynecology, Chosun University Medical School, Gwangju, South Korea.
}

Received July 31, 2007; Revised October 10, 2007; Accepted October 17, 2007; Published October 17, 2007

ABSTRACT - Purpose. Flavonoids have been used as antioxidant, chemopreventive and chemosensitizing agents. In this study, eleven flavonoids containing a variety of hydroxy $(\mathrm{OH})$ and/or methoxy $(\mathrm{OMe})$ groups were evaluated for their antioxidant, cytotoxic and chemosensitizing effects to create a structure-activity relationship (SAR). Methods. 1,1-Diphenyl-2-picrylhydrazyl (DPPH) radical solution-based chemical assay and and 2',7'-dichlorofluorescin diacetate (DCFH-DA) cellular-based assay were used to compare the free radical scavenging activity on the same molar concentration basis using the AML-2/DX100 cells which are characterized by the down-regulated expression of catalase and resulting supersensitiviy to hydrogen peroxide. The chemosensitization and cytotoxicity were determined by the MTT assay in the presence or absence of an anticancer drug using the Pglycoprotein-overexpressing AML-2 subline AML-2/D100 cells. Results. The antioxidant activity of the flavonoid $\left(3,5,7,3^{\prime}, 4^{\prime}-\mathrm{OH}\right)$ was higher than that of the flavonoid $\left(5,7,3^{\prime}, 4^{\prime}-\mathrm{OH}\right)$. Flavonoids substituted with the various number of $\mathrm{OMe}$ decreased antioxidant activity. Flavonoids with $7-\mathrm{OH}$ or $5,7-\mathrm{OH}$ groups have the highest cytotoxicity, and flavonoids with 5,7-OMe group intermediate cytotoxicity. The $\mathrm{IC}_{50}$ values of flavonoid (5,7-OMe, 3', 4',5'-OMe) and flavonoid (5,7-OMe, 4'-OMe), $0.4 \mu \mathrm{M}$ and $1.4 \mu \mathrm{M}$. The $\mathrm{IC}_{50}$ values of flavonoid $\left(5,6,7-\mathrm{OMe}, 3^{\prime}, 4^{\prime}-\mathrm{OMe}\right)$ and flavonoid (5,6,7-OMe, 3',4',5'-OMe), $3.2 \mathrm{uM}$ and $0.9 \mu \mathrm{M}$, respectively, and those of flavonoid (5,6,7-OMe, 3', 4',5'-OMe) and flavonoid (5,7$\left.\mathrm{OMe}, 3^{\prime}, 4^{\prime}, 5^{\prime}-\mathrm{OMe}\right)$ were $0.9 \mu \mathrm{M}$ and $0.4 \mu \mathrm{M}$, respectively. Conclusions. These results suggest that flavonoids with 3-OH group play a positive role in antioxidant activities, flavonoids with 5$\mathrm{OH}$ and/or 7-OH groups show the higher cytotoxicity, and flavonoids with 3'-OMe and/or 5'-OMe groups plays positive but 6-OMe groups negative roles in the P-glycoprotein (Pgp) inhibition. It is believed that these SAR results can be taken into account for the development of flavonoids with high therapeutic index.

\section{INTRODUCTION}

Flavonoids are constituents of fruits, vegetables, nuts, plant-derived beverages, traditional eastern medicines and herb-containing dietary supplements. Flavonoids have been used as antioxidants, chemopreventive or anticancer drugs and chemosensitizers $(1,2)$. Oxygen free radicals and their by-products, which are capable of causing oxidative damage, are collectively referred to as reactive oxygen species (ROS). ROS have been implicated in the pathogenesis of a wide variety of human diseases when produced in excess quantities (3). Cells possess antioxidant systems to protect themselves against dangerous ROS. Therefore, a delicate balance between intracellular oxidants and antioxidants can influence health and aging (4). Because ROS are produced continually, antioxidants must be continually present at their sites of production at high concentrations. A temporary decrease in the antioxidant concentration at a susceptible location, results in the accumulation of oxidative damage, which cannot be prevented or repaired by the late addition of the antioxidants (5). The chemopreventive effects of flavonoids are believed to result from their ability to scavenge ROS whereas the pro-oxidant effect of flavonoids has been shown to be responsible for their anticancer and apoptosis-inducing effects (6-8). Accordingly, exogenous antioxidants have been used for long time. The development of multidrug resistance (MDR) by tumor cells is a major impediment to the success of cancer chemotherapy.

Corresponding Author: Cheol-Hee Choi; Research Center for Resistant Cells and Department of Pharmacology, Chosun University Medical School, Gwangju, South Korea;E-mail: chchoi@chosun.ac.kr 
Overexpression of membrane transporters have been believed as major mechanisms of MDR.

These include the P-glycoprotein (Pgp) (9), the multidrug resistance-associated protein (MRP) (10), and the breast cancer resistance protein (BCRP) (11) that are members of the ATPbinding-cassette superfamily of membrane transporters. Chemosensitizers have been screened and developed in order to circumvent MDR by concomitant administration with anticancer drugs. Flavonoids are considered to be a new class of chemosensitizers that interact with the cytosolic domains of Pgp as well as its ATP binding site (12).

In this study, eleven flavonoids containing hydroxyl $(\mathrm{OH})$ and/or methoxy $(\mathrm{OMe})$ groups (Figure 1) along with four well-known antioxidants were compared for their in vitro antioxidant activity using 1,1-diphenyl-2picrylhydrazyl (DPPH) radical solution-based chemical assay and 2',7'-dichlorofluorescein diacetate (DCFH-DA) cellular-based assay, cytotoxic and chemosensitizing effects and then their structure-activity relationships (SAR) were discussed.

\section{MATERIALS AND METHODS}

\section{Materials}

Flavonoids were purchased from Indofine Chemical Co. (Hillsborough, NJ, USA), the Enhanced chemiluminescence $\left(E C L^{\mathrm{R}}\right)$ detection kit from Amersham (Piscataway, NJ, USA), the TRI reagent LSTM from Molecular Research Center (Cincinnati, OH, USA), the sheep polyclonal antibody for catalase from Biodesign International (Saco, ME, USA), the mouse C219 antibody for Pgp from Signet (Dedham, MA, USA), and the anti-mouse Ig G horseradish peroxidase linked whole antibody from Amersham (Piscataway, NJ, USA).

N-acetyl-L-cysteine (NAC), pyrrolidine dithiocarbamate (PDTC), Vitamin C (Vit C), Vitamin E (Vit E) and others were obtained from Sigma Chemical Co. (ST. Louis, MO, USA).

\section{Cell culture}

The acute myelogenous leukemia cell line, OCIAML-2 line, from the Ontario Cancer Institute (Toronto, Canada), was cultured at $37^{\circ} \mathrm{C}$ in a $5 \%$ (v/v) $\mathrm{CO}_{2}$ atmosphere using minimum essential medium alpha ( $\alpha$-MEM) medium (GibcoBRL, Gland Island, NY, USA) with $10 \%(\mathrm{v} / \mathrm{v})$ heat inactivated fetal bovine serum. The drug-resistant AML-2 sublines were selected from the parental cell line (AML-2/WT) after chronic exposure to either doxorubicin or daunorubicin. The cells were finally cultured in a fixed concentration (100 $\mathrm{ng} / \mathrm{ml}$ ) of each selecting drug. The AML2/DX100 and AML-2/D100 cells were characterized by the down-regulation of catalase and overexpression of Pgp, respectively $(13,14)$, and were used for the determination of antioxidant and chemosensitizing effects, respectively.

\section{Determination of the gene expression for catalase and Pgp}

The total cellular RNA was isolated from the cells using a TRI reagent LS $^{\text {TM }}$ according to the manufacturer's protocol. Catalase expression was detected with using the 5' and 3' primers corresponding to the nucleotides 314-333 (5'TTTGGCTACTTTGAGGTCAC-3') and 734-753 (5'-TCCCCATTTGCATTAACCAG-3') respectively, of the published cDNA sequence (15). Pgp mRNA expression was detected with 5 ' and 3 ' primers corresponding to nucleotides 907-930 (5'CTGGTTTGATGTGCACGATGTTGG-3') and 1179-1201 (3'-GTCATCGACTTCTCCAGAACC GT - 5'), respectively, of the published cDNA (16). Western blotting analysis was performed using a slight modification of the method described previously (17). The proteins transferred onto a nitrocellulose membrane were incubated with the primary antibodies (diluted 1:1000) and the sheep polyclonal antibody for catalase and the mouse C219 antibody for Pgp. The membrane was incubated with the horseradish peroxidaseconjugated secondary antibodies (diluted 1:1000) against each $\operatorname{IgG}$ of the hosts of the primary antibodies for $1 \mathrm{hr}$. The membrane was then stained using the detection reagent of the ECL detection kit. For activity staining of catalase, enzyme samples were separated on a 7\% nondenaturing polyacrylamide gel, and the catalase activity was visualized on the gel using an in situ staining technique (18).

\section{Functional drug accumulation assay}

Cell suspensions $\left(1 \times 10^{6}\right.$ cells $\left./ \mathrm{ml}\right)$ in phosphatebuffered saline (PBS) were exposed to daunorubicin $(5 \mu \mathrm{g} / \mathrm{ml})$ with or without verapamil $(5 \mu \mathrm{M})$, at $37^{\circ} \mathrm{C}$ for $30 \mathrm{~min}$. 


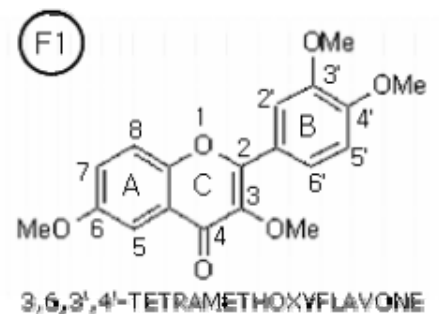<smiles>COc1ccc(-c2oc3cc(O)ccc3c(=O)c2O)cc1OC</smiles>

3,7-DIHYDROXY-3', 4'-DIMETHOKYFLAVONE
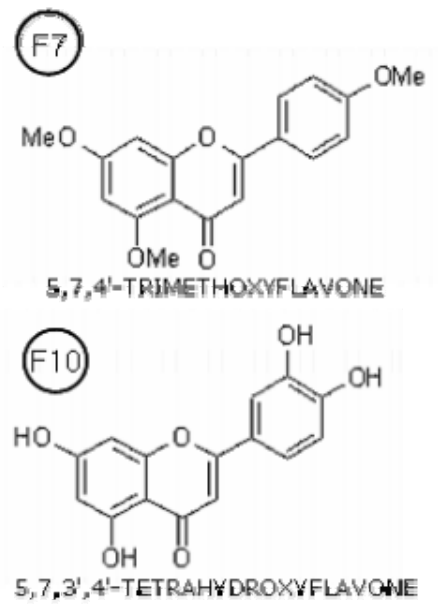<smiles>COc1cc(OC)c2c(=O)cc(-c3cc(OC)c(OC)c(OC)c3)oc2c1</smiles>

$5,7,3^{\prime}, 4^{\prime}, 5^{\prime}$-PENTAMETHOXYFLAVONE<smiles>COc1ccc2c(=O)cc(-c3ccc(OC)c(OC)c3)oc2c1</smiles>
7,3',4'-TRIMETHOXYFLAWONE

(F8)<smiles>COc1ccc(-c2cc(=O)c3ccccc3o2)cc1C</smiles>

3',4'-DIMETHOXYFLAVONE

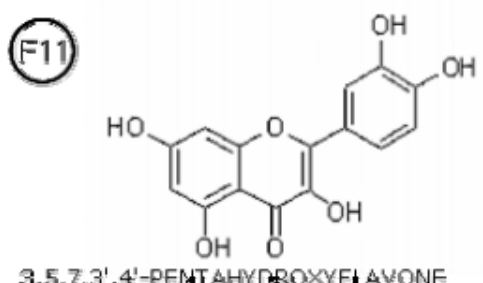<smiles>COc1ccc(-c2cc(=O)c3c(OC)c(OC)c(OC)cc3o2)cc1OC</smiles>

$5,6,7,3^{1}, 4^{\prime}$-PENT AMETHOXFLLAVONE<smiles>COc1cc(-c2cc(=O)c3c(OC)c(OC)c(OC)cc3o2)cc(OC)c1OC</smiles>

$5,6,7,3^{4}, 4^{4}, 5^{-}$-HEXAMETHOXYFLAWONE<smiles>COc1cc(-c2oc3cc(O)cc(O)c3c(=O)c2O)cc(OC)c1OC</smiles>

3,5,7-TRIHYDROKY-3',4,5-TRIMETHOKYFLAVONE

Figure 1. Chemical structure of flavonoids. The numbers of F1 to F11 were designated according to antioxidant activities obtained from the DPPH assay (Figure 3). The number of carbon is labeled only on F1.

Cells were subsequently analyzed for their cellular drug fluorescence by a flow cytometer (Becton Dickinson, San Jose, CA, USA), in which a focused argon laser beam $(488 \mathrm{~nm})$ excited cells in a laminar sheath flow and their fluorescence emissions $(575 \mathrm{~nm})$ were collected to generate a histogram.

\section{Determination of the scavenging activity using DPPH radicals}

The antioxidant activity was assessed according to the radical-scavenging effect of the stable DPPH free radical (13). A $100 \mu \mathrm{M}$ DPPH radical solution was dissolved in $100 \%$ ethanol. The mixture was shaken vigorously and allowed to stand for $10 \mathrm{~min}$ in the dark. The test materials (100 $\mu \mathrm{L}$ each) were added to $900 \mu \mathrm{L}$ of the resulting dark-blue DPPH radical solution in a cuvette. The absorbance at $517 \mathrm{~nm}$ was measured.

\section{Determination of antioxidant activity using DCFH}

DCFH was used to measure the ROS concentration (19). After DCFH diacetate crossed the membrane, it was de-esterified to DCFH, which was oxidized to fluorescent DCF by the ROS. The reaction took place with $1 \times 10^{5}$ of the AML-2/DX100 cells and $1 \mu \mathrm{M}$ DCFH diacetate in $2 \mathrm{ml}$ PBS. The cells were exposed to $700 \mu \mathrm{M}$ $\mathrm{H}_{2} \mathrm{O}_{2}$ for $2 \mathrm{~h}$ after preincubation with the flavonoids and the known antioxidants for 30 $\mathrm{min}$. The fluorescence intensity was determined using a spectrofluorometer (Perkinelmer, Boston, MA, USA). at an excitation wavelength of 485 $\mathrm{nm}$ and an emission wavelength of $530 \mathrm{~nm}$. 


\section{Cytotoxicity and chemosensitization assays}

It is well known that microtubule-disrupting drugs such as vincristine have antimitotic and apoptosis activity (20). The in vitro cytotoxic and chemosensitizing activities of the flavonoids and verapamil were determined by MTT assays with AML-2/D100 cells in the presence or absence of vincristine $(100 \mathrm{ng} / \mathrm{ml})(21)$. The $\mathrm{IC}_{50}$ was defined as the drug concentration that resulted in a $50 \%$ reduction in the number of cells compared with untreated control cells, after 3-day treatment. The $\mathrm{IC}_{50}$ values were determined directly from the semi-logarithmic dose-response curves. The chemosensitizing index was defined as the ratio of the $\mathrm{IC}_{50}$ value in the absence of vincristine to the $\mathrm{IC}_{50}$ value in the presence of vincristine.

\section{Statistical analysis}

The results are expressed as a mean \pm standard error of the mean. The statistical comparisons were made using a Student t' test. A p-value < 0.05 was considered significant.

\section{RESULTS}

Eleven flavonoids (Table 1 and Figure 1) containing a variety of $\mathrm{OH}$ and/or OMe groups were evaluated for their in vitro antioxidant, cytotoxic and chemosensitizing activities and then SAR were created.

\section{Antioxidant activities of flavonoids and SAR}

Two methods using DPPH and DCFH were used to compare the free-radical scavenging activity on the same molar concentration $(100 \mu \mathrm{M})$ basis using the AML-2/DX100 cells which are characterized by the down-regulated expression of catalase and resulting supersensitivity to $\mathrm{H}_{2} \mathrm{O}_{2}$ (Figure 2). In the DPPH assay, flavonoids showed various antioxidant activities according to chemical structures. In advance, the numbers of flavonoids (F1-F11) used in this study were designated from the lowest (F1) to the highest (F11) antioxidant activities obtained from the DPPH assay (Table 1 and Figure 3). As shown in Table 1 and Fig. 3, F11 (3,5,7,3', 4' -OH) and F10 $\left(5,7,3^{\prime}, 4^{\prime}-\mathrm{OH}\right)$ showed highest, F9 $(3,5,7-\mathrm{OH}-$ $3^{\prime}, 4$ ', 5 '-OMe) intermediate and other flavonoids (F2-F8) low antioxidant activities in the DPPH assay. In the DPPH assay, the antioxidant activities of F11 and F10 were higher than four positive control antioxidants, NAC, PDTC, Vit C and Vit $\mathrm{E}$. The antioxidant activities of $\mathrm{F} 9$ were comparable to that of Vit $\mathrm{C}$ and Vit $\mathrm{E}$ whereas antioxidant activities of other flavonoids (F1-F8) were comparable to those of the two chemically distinct antioxidants, NAC or PDTC (Figure 3). In the DCFH assay, the antioxidant activities of F11, F10 and F9 were similar to the results obtained using the DPPH assay whereas other flavonoids (F1 and F2), NAC and Vit C showed quite different results (Figure 4).

As shown in Figure 4, the antioxidant activities of F11 and F10 were comparable with that of PDTC, and those of F3-F8 with that of Vit E. The antioxidant activity of F1 increased to the comparable level with that of F9. However, F2, NAC and Vit C even increased the level of ROS generation in the DCFH assay, suggesting their possible roles as pro-oxidants.

\section{Cytotoxic and chemosensitizing activities of flavonoids and SAR}

The chemosensitizing and cytotoxic activities were determined by the MTT assay in the presence or absence of vincristine, a good substrate for Pgp, respectively, using the AML 2/D100 cells. The AML-2/D100 cells overexpress MDR1 mRNA and Pgp, confirmed by RT-PCR and Western blot analyses, which was responsible for the resistance to daunorubicin and decreased intracellular accumulation that could be inhibited by a Pgp inhibitor verapamil (Figure 5). Four flavonoids (F1, F2, F3 and F5) less than $400 \mu \mathrm{M}$ did not show cytotoxicity and others showed differential cytotoxic activities (Table 1 and Figure 6). As shown in Table 1 and Figure 6, four flavonoids containing $\mathrm{OH}$ groups (F4 and F9F11) have higher cytotoxic activity than others, suggesting an important role of the number of $\mathrm{OH}$ groups in cytotoxicity. However, two flavonoids with OMe groups (F6 and F7) showed relatively high cytotoxicity. These results suggested the number and/or site of OMe groups could be responsible for cytotoxicity, whose SAR was not clear in this study.

Flavonoids have been shown to have bifunctional interactions of their $\mathrm{A}$ and $\mathrm{C}$ rings at the ATP-binding site and the hydrophobic B-ring at a steroid-interacting hydrophobic sequence of Pgp (12). The chemosensitizing activity of flavonoids was determined using the AML2/D100 cells in the presence of vincristine. 


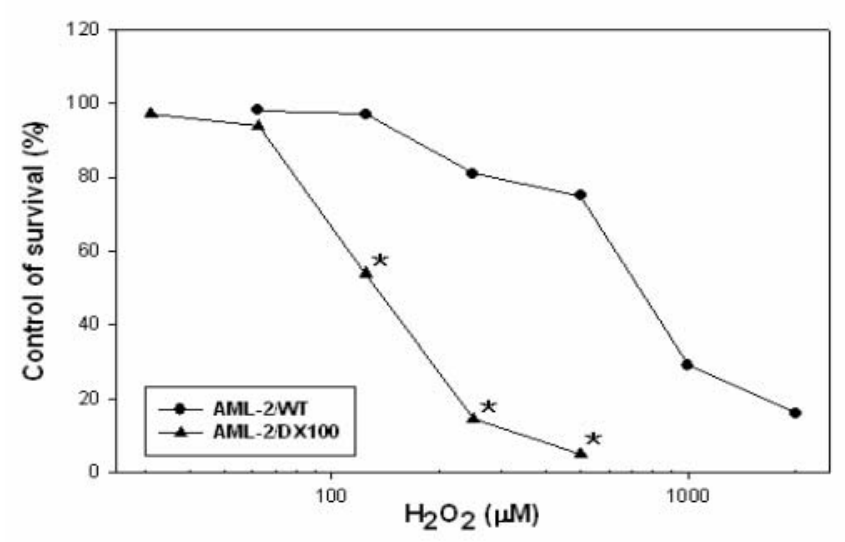

(A)

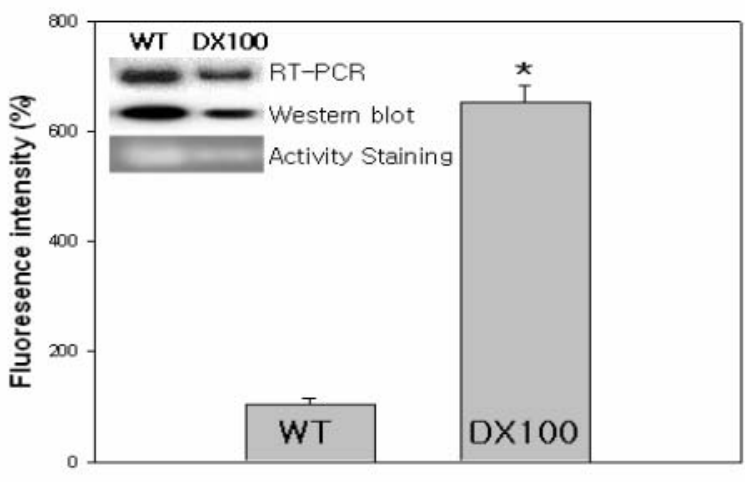

(B)

Figure 2. Supersensitivity to hydrogen peroxide of the AML-2/DX100 characterized by thedown regulated catalase expression. (A) Sensitivity to $\mathrm{H} 2 \mathrm{O} 2$ was determined using theMTT assay, (B) ROS generation after treatment with $700 \mathrm{uM} \mathrm{H} 2 \mathrm{O} 2$ was determinedusing the DCFH assay. Inserts of (B) show catalase expression and activity in theAML-2/WT and AML-2/DX100.* $\mathrm{P}<0.05$

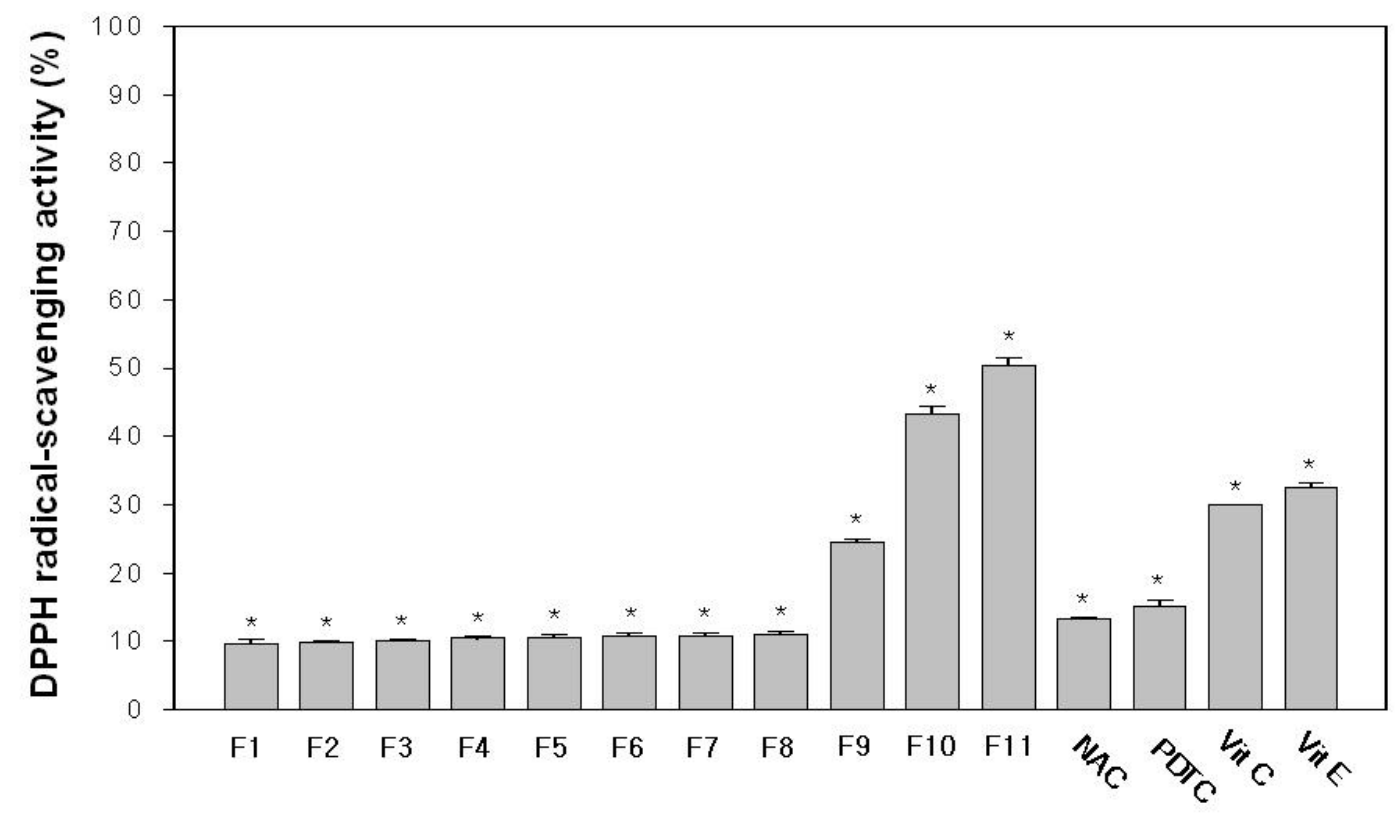

Figure 3. DPPH free radical-scavenging activity of flavonoids and antioxidants. Antioxidant activities of flavonoids and antioxidants were compared on the basis of the same molar concentration of $100 \mu \mathrm{M}$. Means $\pm \mathrm{SE}(\mathrm{n}=3) .{ }^{*} \mathrm{P}<0.05$. 


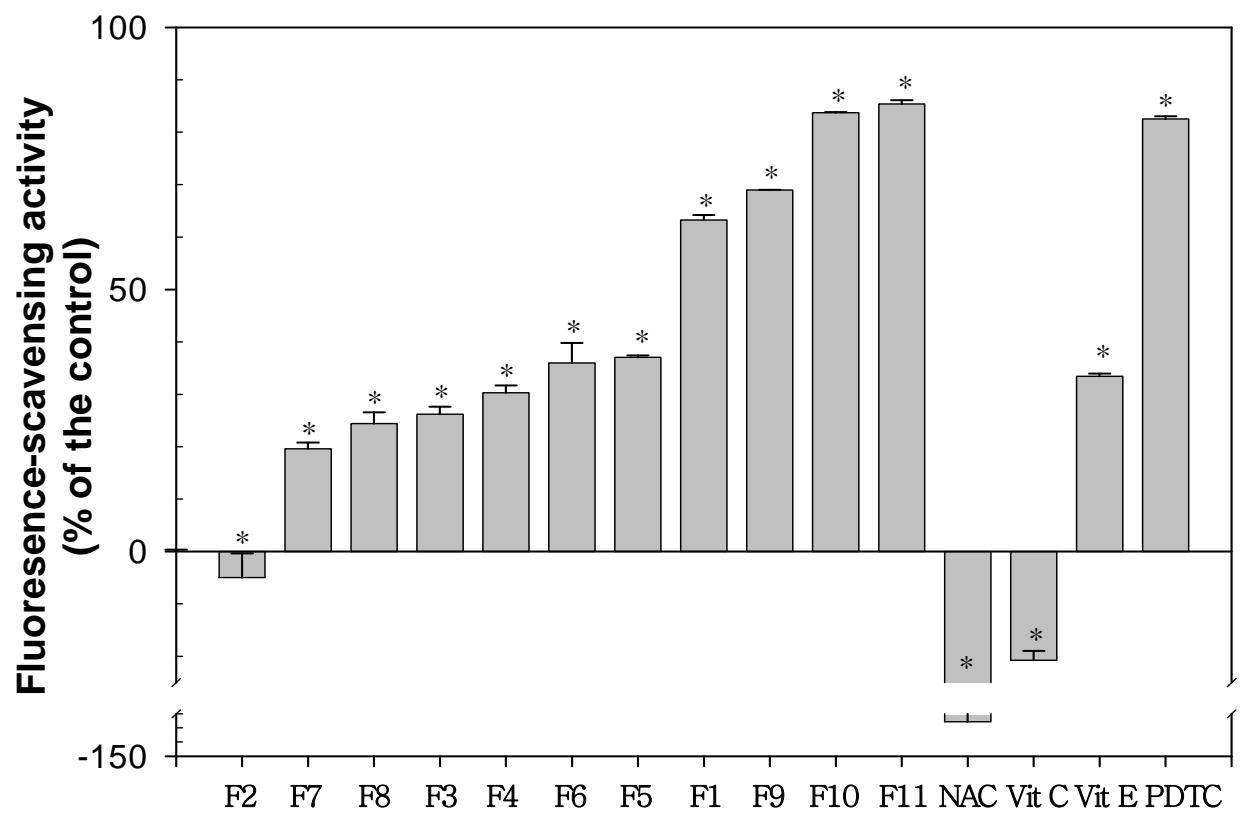

Figure 4. DCFH fluorescence-scavenging activity of flavonoids and antioxidants. The scavenging activity of DCFH fluorescence (\%) was calculated using the equation (Fluorescence control $_{\text {- Fluorescence }}$ sample $_{\text {) }}$ x 100 / Fluorescence control. $_{\text {. }}$ Means $\pm \mathrm{SE}(\mathrm{n}=3) .{ }^{*} \mathrm{P}<0.05$. Other legends are the same as in Figure 3.

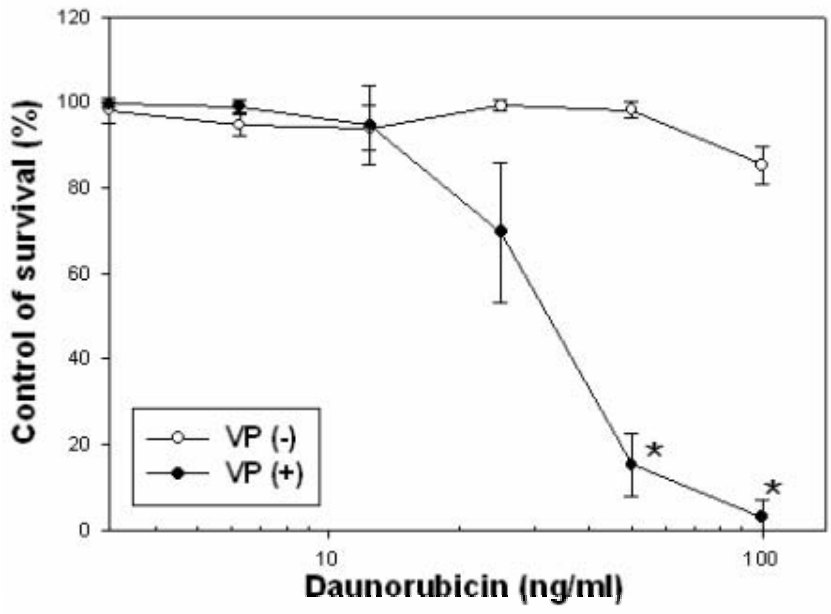

(A)

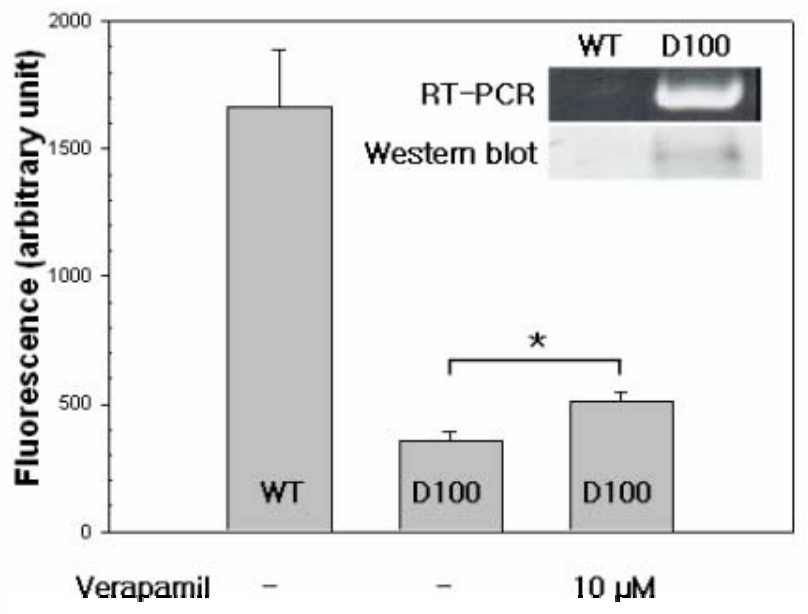

(B)

Figure 5. Reversal of resistance and accumulation of daunorubicin in AML-2/D100 cells by a Pgp inhibitor verapamil. (A) MTT assay using AML-2/D100 cells was performed in the presence or absence of verapamil (VP, $10 \mu \mathrm{M})$ as the function of danourubicin concentrations. (B) Fluorescent intensity of intracellular danourubicin was determined by flow cytometry. Inserts show the profiles of Pgp expression in the AML-2/WT and AML-2/D100. *P $<0.05$. 


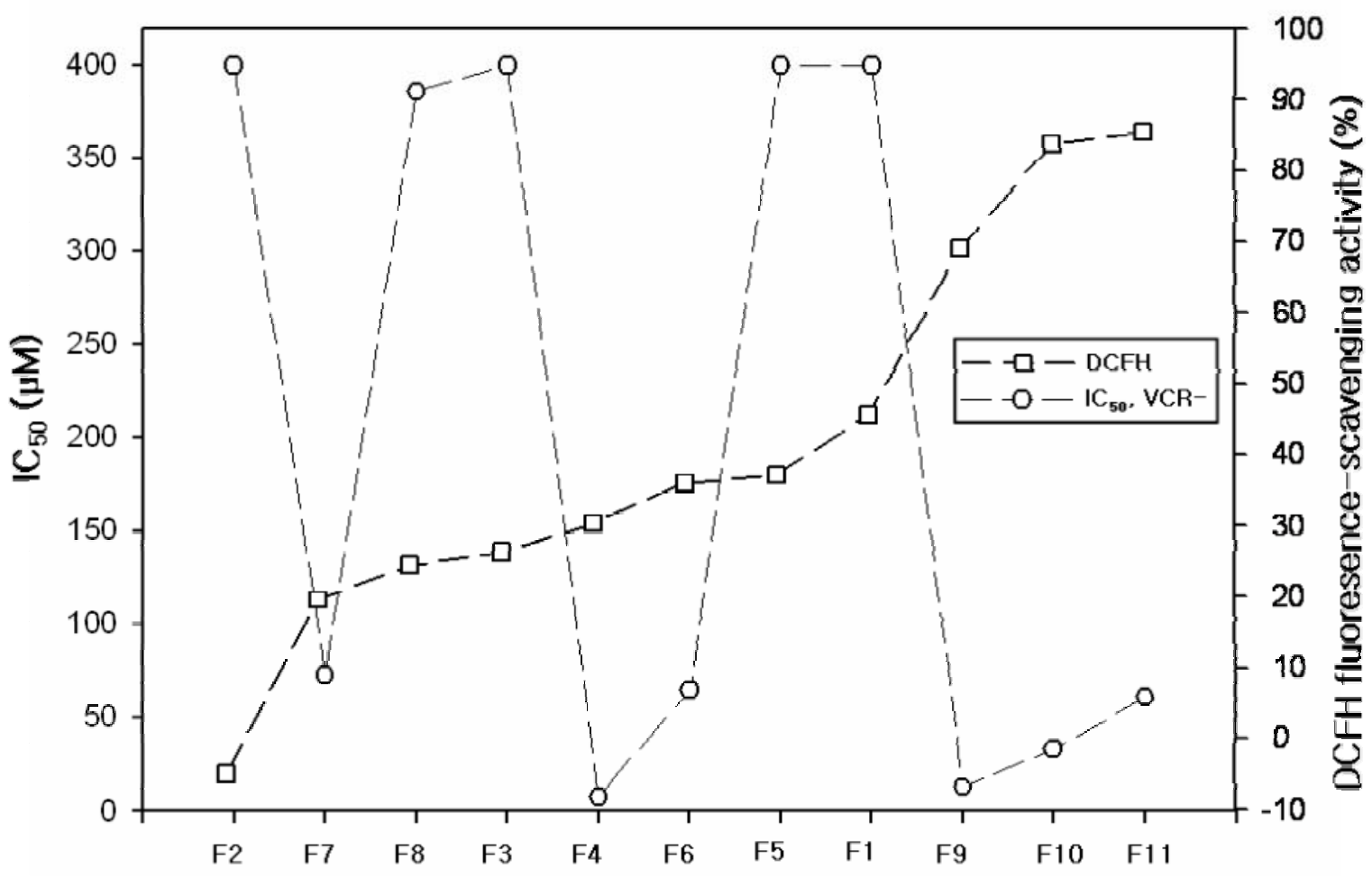

Figure 6. Comparison between $\mathrm{IC}_{50}$ values in the absence of vincristine and $\mathrm{DCFH}$ fluorescence-scavenging activity of the flavonoids. $\mathrm{IC}_{50}$ values were obtained in the absence of vincristine using Pgp-overexpressing AML-2/D100 cells. DCFH fluorescence-scavenging activity was determined using AML-2/DX100 cells as described in "Materials and Methods." VCR, vincristine.

As shown in Table 1 and Figure 7 , the $\mathrm{IC}_{50}$ values of F2 (5,7-OMe, 3',4',5'-OMe) and F7 (5,7-OMe, 4'-OMe), $0.4 \mu \mathrm{M}$ and $1.4 \mu \mathrm{M}$, respectively. The $\mathrm{IC}_{50}$ values of $\mathrm{F} 3\left(5,6,7-\mathrm{OMe}, 3^{\prime}, 4^{\prime}-\mathrm{OMe}\right)$ and $\mathrm{F} 6$ (5,6,7-OMe, 3', 4',5'-OMe), 3.2 $\mu \mathrm{M}$ and $0.9 \mu \mathrm{M}$, respectively. The $\mathrm{IC}_{50}$ values of $\mathrm{F} 6(5,6,7-\mathrm{OMe}$, 3', 4',5'-OMe) and F2 (5,7-OMe, 3',4',5'-OMe) were $0.9 \mu \mathrm{M}$ and $0.4 \mu \mathrm{M}$, respectively. In addition, $\mathrm{IC}_{50}$ values of flavonoids in the presence of vincristine were positively related to their DCFHscavenging activities (Figure 7).

\section{DISCUSSION}

Flavonoids/phenolics can not only be antioxidative but also pro-oxidative, which suggests that the flavonoids can be potentially more of an oxidative risk than a benefit (22). However, the pro-oxidant effect of flavonoids may be a more important mechanism for their anticancer and apoptosis-inducing properties than their antioxidant effect $(23,24)$. The antioxidant activities of NAC and Vit $\mathrm{C}$ showed pro-oxidant activities in the DCFH were comparable to those of PDTC and Vit E, respectively, in the DPPH assay. The former result is consistent with reports showing that Vit $\mathrm{C}$ or NAC behave as a prooxidant rather than an anti-oxidant $(25,26)$. Since the big difference between the both assays is with or without cells, the DCFH assay has the advantage in being able to interpret the permeability of the compounds through the plasma membrane of the cells. Thus, the DCFH assay represents the antioxidant activity of intracellular amounts permeable across the membrane whereas the DPPH assay shows antioxidant activity itself. It is therefore thought that a combination of the DPPH and DCFH methods is more effective in elucidating the differences in the antioxidant activity than that alone. The propensity of a flavonoid to inhibit free-radical mediated events is governed by its chemical structure. The number and positions of the substitutes of the flavone-based compounds can influence the radical-scavenging activity (27). 


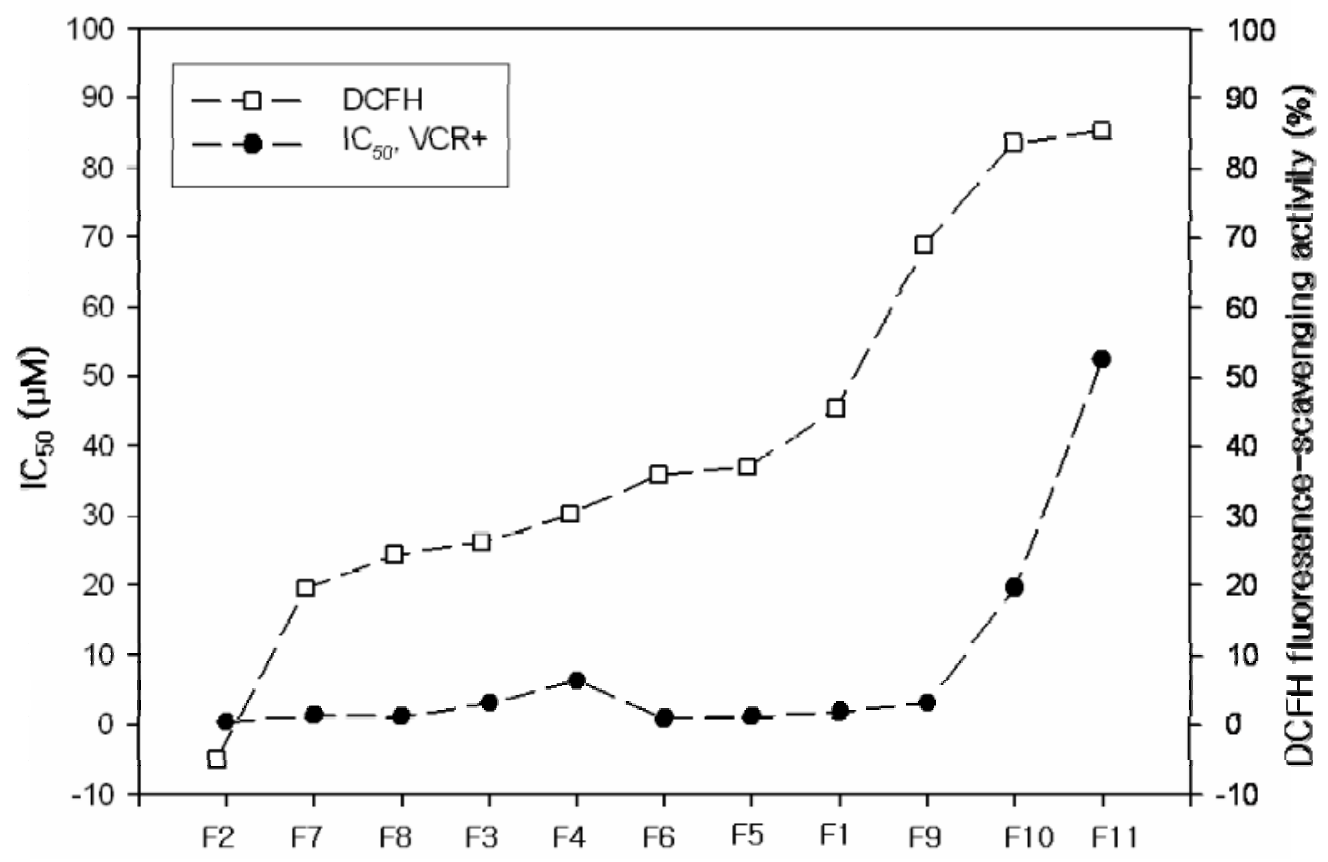

Figure 7. Comparison between $\mathrm{IC}_{50}$ values in the presence of vincristine and $\mathrm{DCFH}$ fluorescence-scavenging activity of the flavonoids. $\mathrm{IC}_{50}$ values were obtained in the presence of vincristine $(100 \mathrm{ng} / \mathrm{ml})$ using AML-2/D100 cells. Other legends are the same as in Figure 6.

Table 1. Antioxidant, cytotoxic and chemosensitizing activities of the flavonoids

\begin{tabular}{|c|c|c|c|c|c|}
\hline \multirow{2}{*}{ Drugs $^{a}$} & \multirow{2}{*}{$\begin{array}{c}\mathrm{DPPH}^{\mathrm{b}} \\
(\%)\end{array}$} & \multirow{2}{*}{$\begin{array}{c}\mathrm{DCFH}^{\mathrm{c}} \\
(\%)\end{array}$} & \multicolumn{2}{|c|}{$\mathrm{IC}_{50}{ }^{\mathrm{d}}(\mu \mathrm{M})$} & \multirow{2}{*}{$\mathrm{CI}^{\mathrm{f}}$} \\
\hline & & & VCR $-^{e}$ & $\mathrm{VCR}+{ }^{\mathrm{e}}$ & \\
\hline F1 (3,6,3',4' - tetramethoxyflavone) & 9.6 & 45.5 & $>400.0$ & 1.9 & $>210.5$ \\
\hline F2 $\left(5,7,3^{\prime}, 4^{\prime}, 5^{\prime}\right.$ - pentametoxyflavone $)$ & 9.9 & -5.0 & $>400.0$ & 0.4 & $>1000.0$ \\
\hline F3 $\left(5,6,7,3^{\prime}, 4^{\prime}\right.$ - pentamethoxyflavone $)$ & 10.1 & 26.2 & $>400.0$ & 3.2 & $>125.0$ \\
\hline F4 (3,7 - dihydroxy-3',4' - dimethoxyflavone) & 10.4 & 30.3 & 7.4 & 6.3 & 1.2 \\
\hline F5 (7,3',4' - trimethoxyflavone) & 10.4 & 37.1 & $>400.0$ & 1.2 & $>333.3$ \\
\hline F6 $\left(5,6,7,3^{\prime}, 4^{\prime}, 5^{\prime}-\right.$ hexamethoxyflavone $)$ & 10.8 & 36.0 & 64.7 & 0.9 & 71.9 \\
\hline F7 $\left(5,7,4^{\prime}\right.$ - trimethoxyflavone) & 10.9 & 19.6 & 72.6 & 1.4 & 51.9 \\
\hline F8 (3',4' - dimethoxyflavone) & 11.0 & 24.4 & 386.0 & 1.2 & 321.7 \\
\hline F9 $\left(3,5,7\right.$ - trihydroxy-3', $4^{\prime}, 5^{\prime}$ - trimethoxyflavone $)$ & 24.5 & 69.0 & 12.6 & 3.2 & 3.9 \\
\hline F10 $\left(5,7,3^{\prime}, 4^{\prime}\right.$ - tetrahydroxyflavone $)$ & 43.2 & 83.7 & 32.7 & 19.6 & 1.7 \\
\hline F11 (5,7,3',4' - pentahydroxyflavone) & 50.2 & 85.4 & 61.0 & 52.5 & 1.2 \\
\hline NAC ( $N$ - acetyl $-\mathrm{L}-$ cysteine $)$ & 13.2 & -125.7 & & & \\
\hline PDTC (pyrrolidine dithiocarbamate) & 15.2 & 82.5 & & & \\
\hline Vit C (Vitamin C) & 29.9 & -20.8 & & & \\
\hline Vit E (Vitamin E) & 32.4 & 33.4 & & & \\
\hline Verapamil & & & 61.0 & 0.4 & 152.5 \\
\hline
\end{tabular}

${ }^{a}$ Number of flavonoids was designated from the lowest to the highest antioxidant activities on the basis of the DPPH assay. ${ }^{\mathrm{b}}$ The DPPH radicals-scavenging activity (\%) was calculated with using the equation $\left(\mathrm{A}_{517}\right.$, control - $\mathrm{A}_{517}$, sample) $\times 100 / \mathrm{A}_{517}$, control. ${ }^{\mathrm{c}}$ The DCFH fluorescence-scavenging activity (\%) was calculated with using the equation (Fluorescence control - Fluorescence sample) x 100 / Fluorescence control. ${ }^{\mathrm{d}}$ Drug concentrations with inhibit $50 \%$ growth of the cells. ${ }^{\mathrm{e}} \mathrm{In}$ the presence $(+)$ or absence $(-)$ of vincristine $(\mathrm{VCR}){ }^{\mathrm{f}}$ Chemosensitizing index $=\mathrm{IC}_{50}(\mathrm{VCR}-) /$ $\mathrm{IC}_{50}(\mathrm{VCR}+)$. 
Flavonoids used in this study are characterized by various combinations of $\mathrm{OH}$ and/or OMe groups. F11 showing the highest antioxidant activity was a just addition of $3-\mathrm{OH}$ to $\mathrm{F} 10$, suggesting an important role of the number of $\mathrm{OH}$ groups and/or 3-OH of the ring $\mathrm{B}$ in the antioxidant activity of flavonoid. With the exception of F4 with two $\mathrm{OH}$ groups, antioxidant activities of flavonoids (F9F11) with more than three $\mathrm{OH}$ groups showed higher than those of other flavonoids, suggesting more positive roles of $\mathrm{OH}$ groups in the antioxidant activity than OMe groups. These results are consistent with reports showing that multiple $\mathrm{OH}$ groups on the molecule have a substantial antioxidant activity and that $\mathrm{OMe}$ groups introduce unfavorable steric effects and increased lipophilicity and membrane partitioning (27). However, F4 with 3,7-OH and 3',4'-OMe showed lower antioxidant activity than two analogues, F5 and F6 without $\mathrm{OH}$ groups did. These results suggest that $\mathrm{OH}$ groups are not always related to the favorable antioxidant activity.

The SAR combining cytotoxicity with chemosensitization was created as follows. Firstly, Flavonoids with the increased number of $\mathrm{OH}$ groups show the higher cytotoxicity. Secondarily, Flavonoids with 3'-OMe and/or 5'-OMe groups play positive but 6-OMe groups negative roles in the Pgp inhibition. The latter suggests that 6-OMe might provide steric hindrance or steric repulsion by the walls of the Pgp pocket. This hypothesis could be supported not only by the finding that the CI values of three flavonoids (F1, F3 and F6) with 6-OMe are less than those of three flavonoids (F2, F5 and F8) without 6-OMe but also by a report that extensions at position 6 of ring A prevent the flavonoid from binding to the ATP site of Pgp (28). On the basis of the above SAR, flavonoids containing 3'-OMe and/or 5'$\mathrm{OMe}$ groups without $\mathrm{OH}$ and 6-OMe groups include F2, F5 and F8, which are consistent with their high chemosensitization indexes. Finally, there was inverse relation between Pgp inhibition and antioxidant activity (Figure 7).

Taken together, these SAR studies indicate that the $\mathrm{OH}$ derivatives of the flavonoids are more likely to have higher antioxidant and cytotoxic effects than their OMe counterparts, and vise versa with respect to the chemosensitizing effect although there are a few exceptions. It is believed that these SAR results can be taken into account for the development of flavonoids with high therapeutic index.

\section{ACKNOWLEDGEMENTS}

This work was supported, in part, by grants from the Ministry of Science and Technology, Korea and the Korea Science and Engineering Foundation through the Research Center for Resistant Cells (R13-2003-009) and by research funds from Chosun University (2004). We would like to thank Dr. H.J. Jang of the Jang Hyo-Juk Cosmetic Clinic for helpful discussion.

\section{REFERENCES}

[1]. Choi, C. H. ABC transporters as multidrug resistance mechanisms and the development of chemosensitizers for their reversal. Cancer Cell Int, 5: 30, 2005.

[2]. Duraj, J., Zazrivcova, K., Bodo, J., Sulikova, M., and Sedlak, J. Flavonoid quercetin, but not apigenin or luteolin, induced apoptosis in human myeloid leukemia cells and their resistant variants. Neoplasma, 52: 273-279, 2005.

[3]. Sen, C. K. and Packer, L. Antioxidant and redox regulation of gene transcription. Faseb J, 10: 709-720, 1996.

[4]. Bonnefoy, M., Drai, J., and Kostka, T. Antioxidants to slow aging, facts and perspectives. Presse Med, 31: 1174-1184, 2002.

[5]. Kohen, R. and Nyska, A. Oxidation of biological systems: oxidative stress phenomena, antioxidants, redox reactions, and methods for their quantification. Toxicol Pathol, 30: 620-650, 2002.

[6]. Galati, G. and O'Brien, P. J. Potential toxicity of flavonoids and other dietary phenolics: significance for their chemopreventive and anticancer properties. Free Radic Biol Med, 37: 287-303, 2004.

[7]. Srinivasan, P., Vadhanam, M. V., Arif, J. M., and Gupta, R. C. A rapid screening assay for antioxidant potential of natural and synthetic agents in vitro. Int J Oncol, 20: 983-986, 2002.

[8]. Tobi, S. E., Gilbert, M., Paul, N., and McMillan, T. J. The green tea polyphenol, epigallocatechin-3-gallate, protects against the oxidative cellular and genotoxic damage of UVA radiation. Int J Cancer, 102: 439-444, 2002.

[9]. Riordan, J. R. and Ling, V. Purification of Pglycoprotein from plasma membrane vesicles of Chinese hamster ovary cell mutants with reduced colchicine permeability. J Biol Chem, 254: 12701-12705, 1979. 
[10]. Cole, S. P., Sparks, K. E., Fraser, K., Loe, D. W., Grant, C. E., Wilson, G. M., and Deeley, R. G. Pharmacological characterization of multidrug resistant MRP-transfected human tumor cells. Cancer Res, 54: 5902-5910, 1994.

[11]. Maliepaard, M., van Gastelen, M. A., de Jong, L. A., Pluim, D., van Waardenburg, R. C., Ruevekamp-Helmers, M. C., Floot, B. G., and Schellens, J. H. Overexpression of the $\mathrm{BCRP} / \mathrm{MXR} / \mathrm{ABCP}$ gene in a topotecanselected ovarian tumor cell line. Cancer Res, 59: 4559-4563, 1999.

[12]. Conseil, G., Baubichon-Cortay, H., Dayan, G., Jault, J. M., Barron, D., and Di Pietro, A. Flavonoids: a class of modulators with bifunctional interactions at vicinal ATP- and steroid-binding sites on mouse P-glycoprotein. Proc Natl Acad Sci U S A, 95: 9831-9836, 1998.

[13]. Kim, H. S., Lee, T. B., and Choi, C. H. Downregulation of catalase gene expression in the doxorubicin-resistant AML subline AML2/DX100. Biochem Biophys Res Commun, 281: 109-114, 2001.

[14]. Choi, C. H. and Ling, V. Isolation and characterization of daunorubicin-resistant AML-2 sublines. Mol Cells, 7: 170-177, 1997.

[15]. Bell, G. I., Najarian, R. C., Mullenbach, G. T., and Hallewell, R. A. cDNA sequence coding for human kidney catalase. Nucleic Acids Res, 14: 5561-5562, 1986.

[16]. Chen, C. J., Chin, J. E., Ueda, K., Clark, D. P., Pastan, I., Gottesman, M. M., and Roninson, I. B. Internal duplication and homology with bacterial transport proteins in the $\mathrm{mdr} 1$ ( $\mathrm{P}-$ glycoprotein) gene from multidrug-resistant human cells. Cell, 47: 381-389, 1986.

[17]. Towbin, H., Staehelin, T., and Gordon, J. Electrophoretic transfer of proteins from polyacrylamide gels to nitrocellulose sheets: procedure and some applications. Proc Natl Acad Sci U S A, 76: 4350-4354, 1979.

[18]. Clare, D. A., Duong, M. N., Darr, D., Archibald, F., and Fridovich, I. Effects of molecular oxygen on detection of superoxide radical with nitroblue tetrazolium and on activity stains for catalase. Anal Biochem, 140: 532-537, 1984.
[19]. LeBel, C. P., Ischiropoulos, H., and Bondy, S. C. Evaluation of the probe 2',7'dichlorofluorescin as an indicator of reactive oxygen species formation and oxidative stress. Chem Res Toxicol, 5: 227-231, 1992.

[20]. Donaldson, K. L., G. L. Goolsby, P. A. Kiener, and A. F. Wahl. Activation of $\mathrm{p} 34^{\text {cdc2 }}$ coincident with taxol-induced apoptosis. Cell Growth Differ. 5: 1041-1050, 1994.

[21]. Pieters, R., Huismans, D. R., Leyva, A., and Veerman, A. J. Adaptation of the rapid automated tetrazolium dye based (MTT) assay for chemosensitivity testing in childhood leukemia. Cancer Lett, 41: 323-332, 1988.

[22]. Decker, E. A. Phenolics: prooxidants or antioxidants? Nutr Rev, 55: 396-398, 1997.

[23]. Rahman, A., Shahabuddin, Hadi, S. M., and Parish, J. H. Complexes involving quercetin, DNA and $\mathrm{Cu}(\mathrm{II})$. Carcinogenesis, 11: 20012003, 1990.

[24]. Hadi, S. M., Asad, S. F., Singh, S., and Ahmad, A. Putative mechanism for anticancer and apoptosis-inducing properties of plant-derived polyphenolic compounds. IUBMB Life, 50: 167-171, 2000.

[25]. D'Agostini, F., Balansky, R. M., Camoirano, A., and de Flora, S. Interactions between Nacetylcysteine and ascorbic acid in modulating mutagenesis and carcinogenesis. Int $\mathrm{J}$ Cancer, 88: 702-707, 2000.

[26]. Kleinveld, H. A., Demacker, P. N., and Stalenhoef, A. F. Failure of N-acetylcysteine to reduce low-density lipoprotein oxidizability in healthy subjects. Eur J Clin Pharmacol, 43: 639-642, 1992.

[27]. Heim, K. E., Tagliaferro, A. R., and Bobilya, D. J. Flavonoid antioxidants: chemistry, metabolism and structure-activity relationships. J Nutr Biochem, 13: 572-584, 2002.

[28]. de Wet, H., McIntosh, D. B., Conseil, G., Baubichon-Cortay, H., Krell, T., Jault, J. M., Daskiewicz, J. B., Barron, D., and Di Pietro, A. Sequence requirements of the ATP-binding site within the C-terminal nucleotide-binding domain of mouse P-glycoprotein: structureactivity relationships for flavonoid binding. Biochemistry, 40: 10382-10391, 2001. 